INDEPENDENT JOURNAL OF MANAGEMENT \& PRODUCTION (IJM\&P)

http://www.ijmp.jor.br $\quad$ v. 11, n. 9, Special Edition (Baltic States), November 2020 ISSN: 2236-269X

DOI: 10.14807/ijmp.v11i9.1421

\title{
STRATEGIC ANALYSIS OF THE COMPETITIVENESS OF EDUCATIONAL PRODUCTS IN THE MANAGEMENT OF HIGHER EDUCATION INSTITUTIONS
}

\author{
Iryna Parasii-Verhunenko \\ Kyiv National Economic University by V.Hetman, Ukraine \\ E-mail:impverh@gmail.com
}

Inna Kuznetsova

Odessa National Economic University, Ukraine

E-mail: innastream27@gmail.com

Hanna Misko

Odessa National Economic University, Ukraine

E-mail: annamisko590@gmail.com

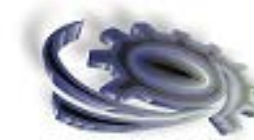

IUIM\&

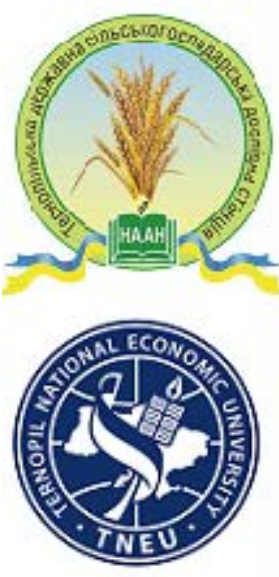

Olena Biriuk

Kyiv National Economic University by V.Hetman, Ukraine

E-mail: birukkneu@ukr.net

Olena Zharikova

National University of Life and Environmental Sciences of Ukraine, Ukraine

E-mail:ele0309@ukr.net

Submission: 8/16/2020

Revision: $8 / 20 / 2020$

Accept: 9/8/2020

\section{ABSTRACT}

The purpose of this article is to develop modern methodological approaches to strategic analysis of the competitiveness of educational products from the standpoint of management of higher education institutions to form a cost management strategy, make fuller use of resource potential and optimize curricula and areas of training professionals. The information base of the study was data on the composition and structure of expenses for preparation of one student, obtained as a result of a survey of 87 institutions of higher education in Ukraine for 2015-2018. Methodical and methodological base for calculating the cost of training one student of higher education institutions was the methodology developed by the State Educational and Scientific Institution "Academy of Financial Management”. Information on the cost of education, the cost of training one student in terms of individual specialties was used on the example of SHEI “Kyiv National Economic University named after Vadym Hetman” and 
DOI: 10.14807/ijmp.v11i9.1421

obtained from the official website of the university. As a result of research the technique of the matrix analysis of an estimation of competitiveness of educational products which is based on a combination of indicative values of indicators is offered. It is proposed to carry out such an assessment on the basis of a two-dimensional matrix, and provide an analytical interpretation of the values of each cell of the matrix, which ensures the implementation of evaluation and search functions of strategic management and forms analytical basis for monitoring costs and revenues for the top management of the institution. The results of the study can be used to implement marketing strategies of higher education institutions aimed at realizing their competitive advantages and more effective use of competitive potential.

Keywords: Strategic analysis; Competitiveness; Educational products; Management; Higher education institutions

\section{INTRODUCTION}

In modern conditions, higher education institutions in Ukraine are increasingly acquiring the characteristics of business companies that accumulate intellectual, material, physical resources and transform them into the final product - knowledge, skills and competencies that are formed in graduates. State educational institutions are responsible to society for the effective use of state property and the development of aggregate domestic intelligence.

The new requirements require higher education to develop effective mechanisms for accelerated adaptation to the economic and educational environment, which is constantly changing under the influence of external and internal factors, including labour market needs for new innovative educational products that determine the competitiveness of educational institutions.

Therefore, the issues of improving the methods of cost-effectiveness analysis of free economic management and finding modern tools for assessing the competitiveness of educational products from the standpoint of higher education and from the standpoint of higher education management, which underlies the development of cost management strategy on the basis of optimization of directions of preparation of specialists taking into account their efficiency.

The use of modern methods of analytical assessment of the effectiveness of cost management of HEIs (higher education institutions) and the search for reserves to reduce 
DOI: 10.14807/ijmp.v11i9.1421

them is based on the information base of management accounting, which allows to allocate costs for each structural unit of the institution or a separate specialty or specialization.

\section{LITERATURE REVIEW}

The globalization of the market of educational services makes new demands on the innovative development of higher education institutions and improving the quality and competitiveness of educational products based on strategic management. Given the specifics of the activities of such economic entities as higher education institutions, it is necessary to consider the features of strategic analysis and strategic management, as their mission and strategic goals are significantly different from other economic entities. Note that this aspect of scientific research is insufficiently highlited in the economic literature.

The origins of the theory of competitive advantages are laid in the concept of Porter's value chain. According to Porter (1980), to achieve competitive advantage and obtain the desired results in the market, it is necessary: to maintain low costs (cost-based leadership strategy); to produce products that are better in quality than the products of competitors, and, preferably, with unique properties (leadership strategy for product differentiation); concentrate activities on a specific market (leadership strategy in a narrow specific area of activity).

In Yershova's research work (2019), strategic cost management is seen as a necessary condition for long-term development of economic entities and a high level of their competitiveness, promotes the efficient use of resources to achieve competitive advantages.

The methodological principles of strategic management accounting and cost analysis of educational institutions are based on the concept of strategic cost management SCM (Strategic Cost Management) developed by Shank and Govindarajan (1999). The essence of the proposed approach to cost analysis based on the value chain is based on the assumption that the costs of higher education institutions are consumed not by end products (educational and research services) but by its business processes and functions as major integrators of resource transformation and results. Based on this, the researchers viewed costs as a function of strategic decisions and linked the achievement of strategic competitive advantages with accounting and cost analysis by type of activity, maintaining low costs (cost-based leadership), while offering more competitive products compared to major competitors (SHANK; GOVINDARAJAN, 1999).

Recently, the problems of strategic management of higher education institutions are increasingly attracting the attention of scientists from around the world. Thus, Danciu and Strat 
DOI: 10.14807/ijmp.v11i9.1421

(2012) using quantitative and qualitative methods of analysis, investigated the peculiarities of the impact of the external environment on the development of strategies for the development of higher education institutions in Romania.

The problems of strategic management of higher education institutions were considered in the works of Chinese scientists, who proposed to take into account the specifics of long-term and medium-term formation of plans based on the differentiation of universities by different levels and types (HU et al., 2019). According to them, vocational schools and private educational institutions are more interested in using modern strategic mechanisms for planning their activities aimed at quality development in order to strengthen their competitive position.

Spanish scientists (YANEZ et al., 2019) studied the issues of managing sustainable development of higher education institutions by improving the strategic planning of universities, standardization of business planning tools and the use of new communication mechanisms of all stakeholders (employers, teachers and students). They emphasized the need for comprehensive planning for the development of all major activities of educational institutions, including educational, scientific and managerial activities. Similar proposals for improving the strategic planning of higher education institutions were made in the study of such scientists as Ramisio, Pinto, Gouveia, Costa, Arezes, which consider the main conditions for their sustainable development to optimize the organizational structure of educational institutions, continuous monitoring of communication of all stakeholders and their interests (RAMISIO et al., 2019).

Russian scientists have proposed a model of strategic management of internal and external risks arising in the education market to successfully formulate strategic plans for higher education institutions. In particular, the following risks such as the risks of reducing the quality of education; risks associated with the inconsistency of curricula with the principles and objectives of state educational policy; demographic risks; risks of imbalance in the number and directions of training of specialists graduated by educational institutions, the needs of the labor market and society; risks of imperfection of the university management system, leading to unjustified costs and reduction of their financial stability (SYREYSHCHIKOVA et al., 2020).

The impact of strategic planning using the model of total quality management (TQM), the model of the European Foundation for Quality Management EFQM and the Balanced Scorecard (BSC) on improving the competitiveness of higher education institutions and 
DOI: 10.14807/ijmp.v11i9.1421

improving their quality is analyzed in the works of such scholars as Fooladvand, Yarmohammadian and Shahtalebi (2015).

Also, the publication of Macedonian scientists is devoted to the problems of implementing the system of total quality management (TQM) in European higher education institutions in the context of globalization in order to increase their competitiveness. These scientists revealed the peculiarities of the implementation of this system in higher education institutions in Macedonia, taking into account the specifics of the educational process associated with the time gap between the incurred costs and the obtained result (TASKOV; MITREVA, 2015).

Mendoza, Gallego-Schmid and Azapagic (2019) proved the feasibility of educational institutions to use the principles of circular economy to create sustainable benefits of educational processes, more efficient use of internal potential and increase their competitiveness.

Jackson's research (2019) is devoted to the problems of balancing digital technologies with the innovative component of professional training of students of higher education institutions. He suggested using absorptive (ambidexterity) strategies as a promising tool for managing strategic change in higher education institutions.

Indonesian scientists have proposed a mechanism for using SWOT-analysis to improve their curricula and optimize the areas of student training in order to improve the strategic management of the development of higher education institutions. They proved the advantages of this methodological approach, which allows to identify the strengths and weaknesses of educational institutions, taking into account the prospects and threats to their development in the future, focusing on market demand for specialists in relevant specialties (THAMRIN; PAMUNGKAS, 2017).

Noteworthy are the studies of Turkish scientists who propose to focus the development strategies of higher education institutions on the development of mechanisms for managing the quality of education (ERYILMAZ et al., 2016).

Johnes and Thanassoulls (2011) investigated the cost structure of UK higher education institutions for the purpose of strategic cost management and proposed predictive models of cost savings with increasing number of students based on the use of parametric regression methods. 
DOI: 10.14807/ijmp.v11i9.1421

The study of Malaysian scientists substantiates the need to improve (reform) the accounting system in higher education institutions in order to provide managers with the necessary information for making strategic decisions. Information blocks on the formation and management of costs, including organizational and accounting information are highlited on the example of 11 institutions of higher education (SHUHIDAN; MASTUKI; NORI, 2015).

Ukrainian scientists also dealt with the problems of strategic management of higher education institutions, in particular Dudko (2012), Kindras (2014), Kozak (2011), Natroshvili (2015), Polianska (2019), Salohubova (2007), Tymoshenko (2019), Chernysh (2012). In the works of these scientists, key attention is paid to the management aspect of strategic research and methods of assessing the competitiveness of educational institutions in terms of demand for certain specialties in the labour market and taking into account modern social and economic transformations based on international experience.

The benefits of using matrix analysis methods to select higher education development strategies are illustrated in a study by Murashko and Nazarko (2010), who attempted to adapt the Ansoff Matrix (1970), the Boston Consulting Group (BCG) and McKinsey to the needs of strategic management of educational institutions at the regional level.

Despite the growing attention of scientists to this issue, it should be noted that in these works the assessment of the competitiveness of HEI is carried out mainly from the standpoint of the needs of external stakeholders and strategic management of the educational institution as a whole with an emphasis on improving the quality of the educational process. At the same time, the issues of methodology of strategic analysis of the competitiveness of individual educational products from the standpoint of their effectiveness for the educational institution, which is the basis of strategic management of their costs are practically remained out of the attention of scientists.

Given the deficit of budget funding in Ukraine for higher education services, the issue of developing a strategy for managing the costs of higher education, which is aimed not only at reducing them, but at optimizing them in direct connection with the results, which depends on a number of factors with the specifics of the activities of higher education institutions. For the successful implementation and functioning of the strategic management system in the HEIs requires appropriate accounting and analytical support based on management accounting, which provides the necessary information to management to implement the planned strategic objectives. 
DOI: 10.14807/ijmp.v11i9.1421

The purpose of this article is to develop methodological approaches to the strategic analysis of the competitiveness of educational products from the standpoint of the leadership of higher educational institutions for the formation of a cost management strategy, a more complete use of resource potential and optimization of educational programs and areas of training.

\section{DATA AND METHODOLOGY}

The information base of the study was empirical data on the composition and structure of costs for the training of one student, obtained as a result of a survey of 87 institutions of higher education in Ukraine for 2015-2018. Methodical and methodological base for calculating the cost of training one student of higher education institutions was the methodology developed by the State Educational and Scientific Institution "Academy of Financial Management” (LOVINSKA; PARASIY-VERHUNENKO; KORYTNYK, 2018). Information on the cost of education, the cost of training one student in terms of individual specialties was obtained from the official website of the SHEI "Kyiv National Economic University named after Vadym Hetman”.

In the course of the research the method of comparative analysis of income and expenses for the preparation of one student in different specialties, coefficient and matrix analysis was used. The advantages of matrix analysis compared to coefficient analysis are proved, in which the indicators that form the matrix are not integrated into a single generalizing indicator, which allows to assess the competitive advantages of individual areas of training, to display them in detail through the visualization of data in two-dimensional space about their strengths and weaknesses.

Positioning the relevant educational service in the relevant segment of the matrix allows you to determine the type of strategy of the institution in relation to the development of the most profitable for the institution areas of training and plan certain strategic goals to optimize costs. Such methodological approach can be used not only to conduct a comparative analysis of the competitive advantages of individual specialties within one educational institution, but also to serve as a methodological basis for analyzing the competitiveness of different educational institutions that train specialists in similar specialties.

\section{RESULTS AND DISCUSSIONS}


DOI: 10.14807/ijmp.v11i9.1421

In modern conditions, the urgency of implementing a cost management system in higher education institutions of Ukraine on the basis of management accounting is associated with strengthening the financial independence and responsibility of educational institutions for their financial condition, which on the one hand, puts forward additional requirements to management to monitor on the other hand, gives him some freedom to choose the optimal organizational structure of the educational institution, aimed at eliminating inefficient units that do not have a corresponding impact on the scientific and educational activities of the institution, which minimizes costs. Equally important strategic goals are to provide a choice of innovative educational products and programs that would meet the modern needs of the labour market.

Regarding the management of costs of higher education institutions, the most acceptable may be the first two areas of competitive advantage in the education market, which involve the creation of innovative educational products that meet the demands of domestic and international labour markets with relatively low cost, which is proposed to base their competitiveness .

The choice of competitiveness indicators depends on the general understanding of the essence of the category "competitiveness". The need to clarify the economic essence of this category is determined by the fact that its correct understanding allows to develop methodological approaches to its evaluation and analysis and to determine the system of evaluation indicators that characterize it. Each researcher uses his own system of concepts, which is determined by the versatility of this category, which should be considered on the one hand as a dynamically evolving process, and on the other - as part of the economic system represented at different levels, from the micro level - from a specific product to the world economy at the macro level.

Studying different methodological approaches to the study of the essence of competitiveness, we should highlight the position of such scientist as Weissman (2004), who proposes to base the distribution (classification) of methodological approaches to the study of the concept of "competitiveness" to put a multilevel object-subject methodological approach based on the principle of clear distinction between the essence of the "competitiveness of the subject" of economic relations (enterprise, industry, country) and the "competitiveness of the object" of these relations (goods, services). In his view, "the essence of the competitiveness of the subject is its ability to create and implement advantages that can compete and win in the market in a certain period of time, and the essence of the competitiveness of the object is a set of its advantages over other objects” (WEISSMAEN, 2004). 
DOI: 10.14807/ijmp.v11i9.1421

Since the subject of our study is the competitiveness of educational products, it is necessary to consider in more detail the essence of this concept and the features of assessing competitiveness, taking into account the specifics of educational activities.

It should be noted that the level of competitiveness of products is assessed not only from the point of view of consumers (buyers), but also from the standpoint of the economic entity depending on its strategic goals and resource capabilities.

An important area of strategic analysis of the costs of free economic education, which generates information for managers on the prospects for the development of certain specialties is the analysis of the competitiveness of educational products. It should take into account the main characteristics of the category “competitiveness”, which include: relative nature, which involves the use of not absolute but relative indicators; ability to dynamic development; ability to earn income and use resources efficiently.

An important issue in developing a methodology for assessing the competitiveness of educational products is to define a system of strategic measurement, which means the identification, development, communication, collection and evaluation of selected performance indicators directly related to the mission of the organization and achieving its goals.

Different methods can be used to conduct a strategic analysis of the competitiveness of individual educational products that have become widespread in academia and in practice. However, the most common of these are coefficient and matrix analysis (PARASII-VERGHUNENKO, 2007).

The advantage of matrix analysis is that the indicators included in the matrix are not integrated into a single aggregate indicator, which allows to illustrate the competitiveness of individual educational products relative to other HEI-competitive competitors in twodimensional space. Positioning of the corresponding educational service in the corresponding segment of a matrix allows to define type of this or that strategy, to outline certain strategic purposes. The simplest version of the matrix includes two main indicators that differ in their values relative to the average value.

The matrix method of competitiveness assessment was first proposed by the Boston Consulting Group (BCG) and, despite numerous shortcomings, has become widespread and has undergone some transformations in relation to key indicators of the matrix: relative market share - market growth; cost efficiency - the effect of differentiation; matrix of market attractiveness - competitiveness of the organization; industry perspective matrix - business 
DOI: 10.14807/ijmp.v11i9.1421

competitiveness; matrix of market evolution - competitive position of business; industry life cycle matrix - relative market positions (PARASII-VERHUNENKO, 2007).

We propose to use a simplified model of the matrix "Marcon" in order to make a strategic choice of the most effective (profitable) priority specialties for the educational institution, in which the key indicator of the effectiveness of individual products is the marginal revenue. The main condition for the possibility of using this methodological approach is the formation of accounting information on income and expenses in terms of individual specialties or faculties on the basis of the introduction of management accounting.

Adaptation of this matrix to assess the effectiveness of cost management of HEIs in the context of individual specialties provides a basis for identifying the main key indicators that determine the effectiveness of cost management in relation to income or other performance indicators. The level of these indicators, or their dynamics, form the cells of the matrix, and serve as information on the development of appropriate strategies of the institution for the development of priority specialties. Such indicators are proposed to include:

- expenses per one hryvnia of income (capacity factor) by specialty (B);

- total annual marginal income by specialty (M);

- dynamics of the average annual contingent of students in a particular specialty $(\Delta \mathrm{Q})$.

The cost per hryvnia of income (capacity factor) (B) is calculated as the ratio of average annual training costs for one student $(\mathrm{V})$ to the cost of one year of student study in the relevant specialty (Z) according to the following formula:

$\mathrm{B}=\frac{V}{Z}$

It is positive to reduce the value of this indicator, which characterizes the effectiveness of the educational product for the educational institution.

Total annual marginal revenue (M) can be calculated by multiplying the specific margin (M1 - margin per unit of product), which is defined as the difference between the cost of one year of study for the relevant specialty $(\mathrm{Z})$ and the cost of training one student during the year $(\mathrm{V})$, on the average annual number of students $(\mathrm{Q})$ :

$$
\mathrm{M}=(\mathrm{Z}-\mathrm{V}) \times \mathrm{Q}
$$

The increase or decrease in the average annual number of students (dynamics) $(\Delta \mathrm{Q})$ is defined as the ratio of the average annual number of students in the current year $\left(Q^{1}\right)$, enrolled in this specialty to the average number of students last year $\left(\mathrm{Q}^{0}\right)$. 
DOI: 10.14807/ijmp.v11i9.1421

$\Delta \mathrm{Q}=\mathrm{Q}^{1}-\mathrm{Q}^{0}$

The assessment of the matrix cell on this indicator, in contrast to the previous ones, is carried out on a three-digit scale: reduction of the contingent of students; a slight increase (up to $10 \%$ ) and a significant increase in the contingent of students (more than 10\%). The choice of such a criterion value is based on the average data on the dynamics of the contingent of students formed over the past three years in the studied institution of higher education in various specialties. If the specialty (specialization) is opened only in the current year, the coding of the value of this indicator is on the maximum scale.

The coding of the cells of the matrix will be carried out by three-digit numbering:

- 1 sign - the value of the coefficient of capacity (1-value less than average; 0 - value greater than average);

- 2 sign - the value of the total margin (profit), which depends on the marginal income per student and the average annual number of students studying in the relevant specialty ( 1 - the value is higher than the average; 0 - the value is less than the average);

- 3 sign - the value of the growth rate, or decrease in the average number of students studying in the specialty (2 - with an increase of more than 10\%; 1 - growth of the contingent from 0 to $10 \%$; 0 - reduction of the contingent compared to the previous year).

Since the positive trend is to reduce the unit cost of educational services, increase marginal income and positive dynamics of the average annual contingent of students, depending on the level of these indicators and their combination, the matrix will have nine cells, each of which must have its own strategy for developing students (Table 1).

As noted above, reducing the cost of training one student is not in itself an end in itself for HEIs, as most of the factors influencing its level depend on the external environment, including raising the salaries of research and teaching staff, legislatively raising the minimum wage, raising technical equipment of the educational process, etc.

Therefore, a general assessment of the effectiveness of cost management should be carried out in conjunction with the indicators of income of the educational institution, which depend on the number of students and the total marginal income of a particular area of training.

The number of students is a catalyst for demand for educational services, which in turn depends on their quality and innovation. Offers of new innovative educational products that 
INDEPENDENT JOURNAL OF MANAGEMENT \& PRODUCTION (IJM\&P)

http://www.ijmp.jor.br

v. 11, n. 9, Special Edition (Baltic States), November 2020

ISSN: 2236-269X

DOI: 10.14807/ijmp.v11i9.1421

are in demand in the education market are the basic principles of the strategy of gaining

competitive advantage based on business diversification, developed in the work of such

scientist as Grant (2008).

Table 1: Analytical interpretation of matrix cells of competitiveness of educational products

\begin{tabular}{|c|c|c|}
\hline $\begin{array}{l}\text { Matrix } \\
\text { cell code }\end{array}$ & $\begin{array}{l}\text { Characteristics of indicators of } \\
\text { competitiveness of educational products }\end{array}$ & $\begin{array}{l}\text { Strategies of development of directions of } \\
\text { preparation of students }\end{array}$ \\
\hline B0M0Q0 & $\begin{array}{l}\text { Specific costs for the training of one student (capacity } \\
\text { factor) is more than the average value of the HEIs } \\
\text { (B0)as a whole; the total margin is less than the average } \\
\text { value for all specialties HEIs (M0); there is a reduction } \\
\text { in the average annual number of students compared to } \\
\text { last year. This area of student training is characterized } \\
\text { by high cost, and there is a decline in demand for this } \\
\text { specialty from entrants }\end{array}$ & $\begin{array}{l}\text { The strategy of the educational institution should be } \\
\text { aimed at reducing the number of students enrolled } \\
\text { in these specialties, as they have high costs, low } \\
\text { demand among applicants, and therefore are } \\
\text { characterized by inefficient use of resource } \\
\text { potential of the educational institution and are not a } \\
\text { strategic source of marginal revenue }\end{array}$ \\
\hline B0M0Q1 & $\begin{array}{l}\text { Specific costs for the training of one student (capacity } \\
\text { factor) is more than the average value of the HEIs (B0) } \\
\text { as a whole; the total margin is less than the average } \\
\text { value for all specialties of the institution (M0); there is } \\
\text { an increase in demand for this specialty, accompanied } \\
\text { by an increase in the average annual number of } \\
\text { students compared to last year to } 10 \% \text {. }\end{array}$ & $\begin{array}{l}\text { This situation is very rare and can occur with the } \\
\text { introduction of new educational products (opening } \\
\text { of new educational programs), which require } \\
\text { additional costs. While maintaining the demand for } \\
\text { this specialty for a certain period of time, } \\
\text { management personnel of HEIs should adjust their } \\
\text { pricing policy to increase tuition fees. }\end{array}$ \\
\hline B0M0Q2 & $\begin{array}{l}\text { Specific costs for the training of one student (capacity } \\
\text { factor) is more than the average value of the HEIs (B0) } \\
\text { as a whole; the total margin is less than the average } \\
\text { value for all specialties of the institution (M0); there is } \\
\text { a significant increase in demand for this specialty, } \\
\text { accompanied by an increase in the average annual } \\
\text { number of students compared to last year by more than } \\
10 \% \text {. }\end{array}$ & $\begin{array}{l}\text { The strategy of management personnel will be } \\
\text { similar to the previous one. An alternative may be } \\
\text { to maintain the tuition fee while increasing the total } \\
\text { margin in the specialty, due to an increase in the } \\
\text { number of students. }\end{array}$ \\
\hline B0M1Q0 & $\begin{array}{l}\text { Specific costs for the training of one student (capacity } \\
\text { factor) is more than the average value of the HEIs (B0) } \\
\text { as a whole; the total margin is greater than the average } \\
\text { value for all specialties HEIs (M0); there is a reduction } \\
\text { in the average annual number of students compared to } \\
\text { last year. This area of student training is characterized } \\
\text { by high cost, high margin and there is a decline in } \\
\text { demand for this specialty from entrants. }\end{array}$ & $\begin{array}{l}\text { The trend is typical for large faculties and the main } \\
\text { competitive advantage is a large overall margin, } \\
\text { which is due to the effect of "scale". HEIs strategy } \\
\text { to support this area of training should be aimed at } \\
\text { adjusting the pricing policy, which is a factor in } \\
\text { increasing the specific margin }\end{array}$ \\
\hline B0M1Q1 & $\begin{array}{l}\text { Specific costs for the training of one student (capacity } \\
\text { factor) is more than the average value of the HEIs (B0) } \\
\text { as a whole; the total margin is greater than the average } \\
\text { value for all specialties HEIs (M0); there is an increase } \\
\text { in the average annual number of students compared to } \\
\text { last year within } 10 \% \text {. This area of student training is } \\
\text { characterized by high costs, high margins and growing } \\
\text { demand for this specialty from applicants. }\end{array}$ & $\begin{array}{l}\text { The strategy of the educational institution in } \\
\text { relation to these areas of training should be aimed at } \\
\text { reducing costs while maintaining leadership in } \\
\text { increasing the number of students. An alternative } \\
\text { may be to increase the price (tuition fees) which will } \\
\text { not affect the demand for this specialty. }\end{array}$ \\
\hline B0M1Q2 & $\begin{array}{l}\text { Specific costs for the training of one student (capacity } \\
\text { factor) is more than the average value of the HEIs (B0) } \\
\text { as a whole; the total margin is higher than the average } \\
\text { value for all specialties HEIs (M1); there is an increase } \\
\text { in the average annual number of students compared to } \\
\text { last year within } 10 \% \text {. This area of student training is } \\
\text { characterized by high cost, high margin and a } \\
\text { significant increase in demand for this specialty from } \\
\text { entrants. }\end{array}$ & $\begin{array}{l}\text { This situation can occur at high unit costs, or low } \\
\text { cost of training per student, but while maintaining } \\
\text { high demand for this specialty. The strategy of the } \\
\text { educational institution in these areas of training } \\
\text { should be aimed at reducing costs while } \\
\text { maintaining leadership in increasing the number of } \\
\text { students and the formation of pricing strategies } \\
\text { taking into account the elasticity of demand for this } \\
\text { specialty with increasing prices (tuition fees). }\end{array}$ \\
\hline B1M0Q0 & $\begin{array}{l}\text { Specific cost of training one student (capacity factor) is } \\
\text { less than the average value of the overall HEIs (B1), } \\
\text { which positively characterizes the effectiveness of cost } \\
\text { management; the total margin is less than the average } \\
\text { value for all specialties HEIs (M0); there is a decrease } \\
\text { in the average annual number of students compared to } \\
\text { last year (Q0). This area of student training is }\end{array}$ & $\begin{array}{l}\text { When the relative profitability of the specialty of the } \\
\text { position value "price - the cost" of educational } \\
\text { institution should enhance the offensive strategy to } \\
\text { promote this educational product (a more } \\
\text { aggressive vocational work), to create favourable } \\
\text { conditions to attract the entry of additional troops. }\end{array}$ \\
\hline
\end{tabular}


DOI: 10.14807/ijmp.v11i9.1421

\begin{tabular}{|c|c|c|}
\hline & $\begin{array}{l}\text { characterized by relatively low cost, low margin and } \\
\text { reduced demand for this specialty by entrants. }\end{array}$ & \\
\hline B1M0Q1 & $\begin{array}{l}\text { Specific cost of training one student (capacity factor) is } \\
\text { less than the average value of the overall HEIs (B1), } \\
\text { which positively characterizes the effectiveness of cost } \\
\text { management; the total margin is less than the average } \\
\text { value for all specialties HEIs (M0); there is an increase } \\
\text { in the average annual number of students compared to } \\
\text { last year (Q1) within } 10 \% \text {. }\end{array}$ & $\begin{array}{l}\text { This area of student training is characterized by } \\
\text { relatively low cost, low margin and increased } \\
\text { demand for this specialty from entrants. This } \\
\text { situation occurs very rarely and is possible when } \\
\text { opening new specialties. }\end{array}$ \\
\hline B1M0Q2 & $\begin{array}{l}\text { Specific cost of training one student (capacity factor) is } \\
\text { less than the average value of the overall HEIs (B1), } \\
\text { which positively characterizes the effectiveness of cost } \\
\text { management; the total margin is less than the average } \\
\text { value for all specialties HEIs (M0); there is an increase } \\
\text { in the average annual number of students compared to } \\
\text { last year (Q1) within } 10 \% \text {. }\end{array}$ & $\begin{array}{l}\text { This area of student training is characterized by } \\
\text { relatively low cost, low margin and rapid growth in } \\
\text { demand for this specialty from applicants, which is } \\
\text { typical for new specialties in demand in the labour } \\
\text { market. }\end{array}$ \\
\hline B1M1Q0 & $\begin{array}{l}\text { Specific cost of training one student (capacity factor) is } \\
\text { less than the average value of the HEIs as a whole; the } \\
\text { total margin is higher than the average value for all } \\
\text { specialties HEIs; reducing demand for this specialty }\end{array}$ & $\begin{array}{l}\text { The profitability of this specialty is due to low } \\
\text { capacity consumption, high margin, which is also a } \\
\text { consequence of the large number of students } \\
\text { studying in this area of training, but in the labour } \\
\text { market there is a decrease in demand for it. The } \\
\text { marketing strategy of the educational institution in } \\
\text { this case should be aimed at active advertising of } \\
\text { this specialty, intensification of career guidance } \\
\text { work and revision of pricing policy. }\end{array}$ \\
\hline B1M1Q1 & $\begin{array}{l}\text { Specific cost of training one student (capacity factor) is } \\
\text { less than the average value of the HEIs as a whole; the } \\
\text { total margin is higher than the average value for all } \\
\text { specialties HEIs; increase in the number of the average } \\
\text { annual contingent of students to } 10 \% \text {. }\end{array}$ & $\begin{array}{l}\text { The specialties that fall into this center are the most } \\
\text { competitive in terms of efficiency, are less costly } \\
\text { and should be preferred in the formation of the } \\
\text { strategy of HEIs in conducting career guidance } \\
\text { work; }\end{array}$ \\
\hline B1M1Q2 & $\begin{array}{l}\text { Specific cost of training one student (capacity factor) is } \\
\text { less than the average value of the HEIs as a whole; the } \\
\text { total margin is higher than the average value for all } \\
\text { specialties HEIs; increase in the number of the average } \\
\text { annual contingent of students more than } 10 \% \text {. }\end{array}$ & $\begin{array}{l}\text { The specialties that fall into this center are the most } \\
\text { competitive in terms of efficiency, are less } \\
\text { expensive and should be preferred in the formation } \\
\text { of the strategy of HEIs in conducting career } \\
\text { guidance work; }\end{array}$ \\
\hline
\end{tabular}

*Source: Developed by the authors

It is advisable to include the following general indicators to develop a strategy for the development of individual areas of preparation for the matrix: the ratio of training costs per student to the average annual tuition cost of one student (capacity factor), total margin, growth rate of average annual number of students in a particular specialty.

This approach is especially important for non-governmental (private) higher education institutions, which can independently set pricing policies, which in turn depend on market factors.

An extended version of the matrix is proposed to do this, which includes a larger number of indicators that characterize the competitiveness of educational products (Table 2).

Table 2: Initial data for constructing a matrix for assessing the effectiveness of the cost management strategy in the context of individual specialties in HEIs "XXX" for 2019 (full-time education) 
INDEPENDENT JOURNAL OF MANAGEMENT \& PRODUCTION (IJM\&P)

http://www.ijmp.jor.br

v. 11, n. 9, Special Edition (Baltic States), November 2020

ISSN: 2236-269X

DOI: 10.14807/ijmp.v11i9.1421

\begin{tabular}{|c|c|c|c|c|c|c|c|}
\hline & $\begin{array}{l}\text { Costs } \\
\text { per } \\
\text { student, } \\
\text { UAH }\end{array}$ & $\begin{array}{c}\text { Cost of } 1 \\
\text { year of } \\
\text { study, } \\
\text { UAH }\end{array}$ & $\begin{array}{c}\text { Capacity } \\
\text { factor }\end{array}$ & $\begin{array}{c}\text { Average } \\
\text { annual } \\
\text { contingent, } \\
\text { people }\end{array}$ & $\begin{array}{c}\text { Specific } \\
\text { margin } \\
\text { (profit), } \\
\text { UAH }\end{array}$ & $\begin{array}{c}\text { Total } \\
\text { margin }\end{array}$ & $\begin{array}{c}\text { Growth rate } \\
\text { of students } \\
\text { compared to } \\
\text { the previous } \\
\text { year,\% }\end{array}$ \\
\hline Economy & 21507 & 23004 & 0,93 & 240 & 1497 & 359280 & -15 \\
\hline $\begin{array}{l}\text { International } \\
\text { economics }\end{array}$ & 23774 & 24948 & 0,95 & 180 & 1174 & 211320 & +3 \\
\hline Political science & 19681 & 19764 & 1,00 & 20 & 82 & 1640 & +5 \\
\hline Sociology & 19608 & 19764 & 0,99 & 16 & 156 & 2496 & +1 \\
\hline $\begin{array}{l}\text { Accounting and } \\
\text { Taxation }\end{array}$ & 21498 & 23004 & 0,93 & 90 & 1506 & 135540 & -8 \\
\hline $\begin{array}{l}\text { Finance and } \\
\text { Banking }\end{array}$ & 21571 & 24948 & 0,86 & 140 & 3376 & 472640 & -24 \\
\hline Management & 19926 & 23004 & 0,87 & 45 & 3078 & 138510 & -6 \\
\hline Marketing & 21493 & 23004 & 0,93 & 102 & 1511 & 154122 & -12 \\
\hline $\begin{array}{l}\text { Entrepreneurship, } \\
\text { exchange trading }\end{array}$ & 21500 & 23004 & 0,93 & 80 & 1503 & 120240 & +8 \\
\hline Law & 23068 & 23112 & 1,00 & 152 & 43 & 6536 & -20 \\
\hline Computer science & 21760 & 23004 & 0,95 & 56 & 1243 & 69608 & +15 \\
\hline System Analysis & 21821 & 23004 & 0,95 & 30 & 1183 & 35490 & +9 \\
\hline Cybersecurity & 21459 & 23004 & 0,93 & 22 & 1544 & 33968 & +25 \\
\hline Tourism & 20220 & 23004 & 0,88 & 42 & 2783 & 116886 & +14 \\
\hline $\begin{array}{l}\text { Public } \\
\text { Administration }\end{array}$ & 21697 & 23004 & 0,94 & 10 & 1307 & 13070 & +7 \\
\hline $\begin{array}{l}\text { Personnel } \\
\text { management }\end{array}$ & 21169, & 23004 & 0,92 & 60 & 1835 & 110100 & +18 \\
\hline Sum & 341759 & 365580 & 14,98 & 1285 & 23820 & 30608700 & $\mathrm{x}$ \\
\hline Average value & 21360 & 22848 & 0,94 & 80 & 1489 & 119120 & $\mathrm{x}$ \\
\hline
\end{tabular}

Source: Compiled by the authors according to the data POLJANSJKA and TYMOSHENKO (2019)

For example, according to the specialty “Accounting and Taxation” the code takes on the meaning of B1M1Q0. The value of the efficiency ratio is 0.93 with an average value of 0.94 (code 1), the value of the indicator "Total margin” - 1386 UAH with an average value of UAH 1.379 (code 1), the value of the indicator "ontingent growth rate” is minus 8 (code 0 ). Coding of the cells of the matrix for different specialties in HEIs "XXX" are given in Table 3.

Matrix analysis of the effectiveness of different areas of training of students (specialties) provides grounds for such conclusions regarding the development strategy of the educational institution. The most promising new specialties, the demand for which is actively growing in the labour market are: “cybersecurity” and "tourism".

Table 3: Coding of the cells of the matrix for assessing the effectiveness of the cost management strategy for individual specialties in the HEIs "XXX” for 2019 (full-time education)

\begin{tabular}{|l|c|c|c|}
\hline & $\begin{array}{c}\text { Capacity } \\
\text { factor }\end{array}$ & $\begin{array}{c}\text { Total margin } \\
\text { (profit), UAH }\end{array}$ & $\begin{array}{c}\text { Growth rate of students } \\
\text { compared to the previous } \\
\text { year, \% }\end{array}$ \\
\hline Economy & 1 & 1 & 0 \\
\hline International economics & 0 & 1 & 1 \\
\hline Political science & 0 & 0 & 1 \\
\hline
\end{tabular}


INDEPENDENT JOURNAL OF MANAGEMENT \& PRODUCTION (IJM\&P)

http://www.ijmp.jor.br

v. 11, n. 9, Special Edition (Baltic States), November 2020

ISSN: 2236-269X

DOI: 10.14807/ijmp.v11i9.1421

\begin{tabular}{|l|l|l|l|}
\hline Sociology & 0 & 0 & 1 \\
\hline Accounting and Taxation & 1 & 1 & 0 \\
\hline Finance and Banking & 1 & 1 & 0 \\
\hline Management & 1 & 1 & 0 \\
\hline Marketing & 1 & 1 & 0 \\
\hline Entrepreneurship, Exchange Trading & 1 & 1 & 1 \\
\hline Law & 0 & 0 & 0 \\
\hline Computer Science & 0 & 0 & 1 \\
\hline System Analysis & 0 & 0 & 1 \\
\hline Cybersecurity & 1 & 0 & 2 \\
\hline Tourism & 1 & 0 & 2 \\
\hline Public Administration & 1 & 0 & 1 \\
\hline Personnel Management & 1 & 0 & 1 \\
\hline
\end{tabular}

Source: Compiled by the author according to Table 2

The efficiency matrix of different specialties in HEIs "XXX" is shown in Figure4.

These specialties fall into the cell of the matrix with the code B1M0Q2, which is characterized by a low efficiency ratio due to the relatively low unit cost of training one student and a relatively low total margin, due to the small number of students enrolled in this specialty.

\begin{tabular}{|c|c|c|c|c|}
\hline \multirow{6}{*}{ 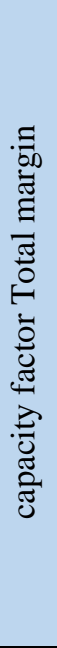 } & 11 & $\begin{array}{c}\mathbf{1 1 0} \\
\text { Economy; Accounting and } \\
\text { taxation; Finance and banking; } \\
\text { Management; } \\
\text { Marketing }\end{array}$ & $\begin{array}{c}111 \\
\text { Entrepreneurship, exchange } \\
\text { trade; }\end{array}$ & $\begin{array}{c}112 \\
-\end{array}$ \\
\hline & 10 & $\begin{array}{c}100 \\
-\end{array}$ & $\begin{array}{c}\mathbf{1 0 1} \\
\text { Public administration } \\
\text { personnel management; }\end{array}$ & $\begin{array}{c}102 \\
\text { Cybersecurity } \\
\text { Tourism } \\
\end{array}$ \\
\hline & 01 & $\begin{array}{c}010 \\
- \\
\end{array}$ & $\begin{array}{c}011 \\
\text { International Economics }\end{array}$ & $\begin{array}{c}012 \\
- \\
\end{array}$ \\
\hline & 00 & $\begin{array}{l}\mathbf{0 0 0} \\
\text { Law }\end{array}$ & $\begin{array}{c}\mathbf{0 0 1} \\
\text { Politology } \\
\text { Computer Science; } \\
\text { System analysis; } \\
\end{array}$ & 002 \\
\hline & код & 0 & 1 & 2 \\
\hline & & The growt & the contingent of students & \\
\hline
\end{tabular}

Figure 1: Matrix for evaluating the effectiveness of various specialties

in HEIs “XXX” for 2018

Source: Created by the author according to Tables 6 and 7

At the same time, there is a high growth rate of enrollment of students in this area of training (25\% and 14\%, respectively). The strategy of the educational institution should be aimed at the active promotion of this area of training through marketing technologies to attract additional students.

A high level of efficiency is also observed in the specialties that fall into the cell of the matrix with the code B1M1Q1, which differs from the leading specialties at a slightly slower growth rate of demand for the specialty. These specialties include such as: "Personnel management”; “Entrepreneurship, exchange trade”. The growth rate of enrollment of students 
DOI: 10.14807/ijmp.v11i9.1421

in these specialties is in the range from 0 to $10 \%$. At the same time, there is a high relative to the average level of margin per student and a low level of efficiency, which was below average, which indicates the effectiveness of educational obedience in these specialties. The strategy for the development of these areas of training should be aimed at strengthening measures to further involve students.

The traditional directions of preparation of HEIs of an economic direction on specialties are rather high efficiency: "Economy”; “Accounting and taxation”; "Finance and banking”; "Management”; “Marketing”, which fall from the cell with the code B1M1Q0. However, these areas of training have a clear tendency to reduce the number of students and reduce the average number of contingents. For example, in the specialty "Economics” the number of students for the study period decreased by 15\%, “Accounting and taxation” - by 8\%, “Finance and banking” - by 24\%, “Management” - by 6\%, “Marketing” - by 12\%. Despite the large number of students studying in these specialties and exceeding the average value of the contingent in the institution, there is a clear trend to reduce the demand for specialists in these specialties in the labour market, which is reflected in the number of applicants for this specialty as in the studied institution and in other HEIs of economic orientation. However, these specialties are characterized by relatively low consumption capacity and high efficiency.

The higher education institution should pay special attention to the new specialty "Public management and administration", which falls under the code B1M0Q1, which has a high level of efficiency compared to the average, low overall margin (due to small enrollment) and growing demand for specialists in this field. To do this, the HEIs should review the cost of training in this specialty in the direction of reduction to further attract students.

Specialists in such specialties as: "International economy”, "Politology”; “Computer Science"; "System analysis"are in stable demand on the labour market, which shows an increase in the average annual number of students. However, the cost of these specialties compared to others is high, which has a negative impact on the value of "capacity" and "total margin”. These specialties fall into the cell of the matrix with the code B0M0Q1. Strategic actions of the HEIs in relation to these specialties based on the analysis of price proposals in the educational market should be aimed at raising the price for these educational services.

According to the data, the list of outsiders includes the specialty "Law", which is located in the cell of the matrix with the code B0M0Q0, which is characterized by high cost of 
DOI: 10.14807/ijmp.v11i9.1421

educational services, low margins and reduced demand for this specialty in the labour market, which reduces the average annual number of students $-20 \%$ ).

\section{CONCLUSIONS AND RECOMMENDATIONS}

When conducting an analytical substantiation of the development strategy of higher education institutions as a whole and its individual structural units from the standpoint of cost management, it is necessary to take into account certain features of their functioning in the educational market. Firstly, there is an indirect link between the costs incurred and the performance of the institution, which does not coincide in time and is not always characterized by financial performance. Secondly, making decisions to improve the educational process, which are usually accompanied by increased costs, are carried out at the lower and middle levels of government without taking into account their impact on the dynamics of total expenditures of the HEIs, especially in long term.

Therefore, proposals for improving the educational process in the lower levels of the institution should be consistent with the overall budgets of revenues and expenditures in general for HEIs and not contradict the strategic plans of the institution and its financial capabilities. Thirdly, the modern format of cost accounting, planning and the entire financial system of the HEIs are fund-oriented, which involves controlling the use of resources in terms of compliance with the targeted use of budget funds, or compliance with estimates, which is formed by the elements of costs, which complicates the control of costs at their places of origin and reduces its informativeness in terms of strategic management.

The proposed tools of matrix analysis of the effectiveness of different specialties, taking into account trends in labour market demand can be implemented under the conditions of introduction of management accounting in HEIs, which allows the separation of information on income and expenses by individual specialties (or other centers of responsibility, such as faculties). To form strategies for the development of higher education institutions, the matrix can be supplemented by other indicators that characterize the competitiveness of educational products, in particular, non-financial indicators of the quality of the educational process. The use of such a methodological approach will not only facilitate a comparative analysis of the competitive advantages of individual specialties within one educational institution, but will also serve as a methodological basis for analyzing the competitiveness of various educational institutions that train specialists in similar specialties.

\section{REFERENCES}


DOI: 10.14807/ijmp.v11i9.1421

ANSOFF, H. I. (1970) Strategic issue management. Strategic management journal, n. 1, p. 26-31.

CHERNYSH, O. V. (2012) Systemni chynnyky konkurentospromozhnosti vyshhogho navchaljnogho zakladu [Systemic factors of the competitiveness of a higher education institution]. Visnyk KNUTD, n. 4, p. 475-479. (in Ukrainian).

DANCIU, A.; STRAT, V. A. (2012) Strategic Planning at the Level of Higher Education Institution: Quantitative Elements Used in the Early Stages of the Process. Procedia - Social and Behavioral Sciences, v. 58, p. 1-10.

DUDKO, P. M. (2012) Strateghichne upravlinnja vyshhym navchaljnym zakladom: teoretyko-metodychni aspekty [Strategic management of a higher educational institution: theoretical and methodological aspects]. Visnyk KNUTD, n. 4, p. 429-439. (In Ukrainian)

FOOLADVAND, M.; YARMOHAMMADIAN, M.; SHAHTALEBI, S. (2015) The Application Strategic Planning and Balance Scorecard Modelling in Enhance of Higher Education. Procedia - Social and Behavioral Sciences, v. 18613, p. 950-954.

GRANT, R. M. (2008) Modern strategic analysis [Sovremenny j strategicheskij analiz]. SPb.: Piter. (in Russian).

HU, J; LIU, L; CHEN, Y; QIN, J. (2018) Strategic planning and the stratification of Chinese higher education institutions. International Journal of Educational Development, v. 63, p. 36-43. https://doi.org/10.1016/j.ijedudev.2017.03.003

JACKSON, N. C. (2019) Managing for competency with innovation change in higher education: Examining the pitfalls and pivots of digital transformation. Business Horizons, v. 62, n. 6, p. 761-772. https://doi.org/10.1016/j.bushor.2019.08.002

JERSHOVA, N. Ju. (2019) Strateghichnyj upravlinsjkyj oblik v umovakh innovacijnoorijentovanoji modeli ekonomiky : monoghrafija [Strategic management accounting in an innovation-oriented model of the economy: monograph] Kharkiv : FOP Liburkina L.M. (in Ukrainian)

JOHNES, G.; JOHNES, J.; THANASSOULLS, E. (2011) Costs and Efficiency of Higher Education Institutions in England: A DEA Analysis. Journal of the Oparational Research Society, n. 62, p. 1282-1297.

KINDRASJ, O. V. (2014) Pytannja formuvannja konkurentnogho potencialu vyshhogho navchaljnogho zakladu jak sub jekta rynku [On the formation of the competitive potential of a higher educational institution as a market entity]. Ekonomika i upravlinnja, n 1, p. 26-32. (in Ukrainian)

KOZAK, O. M. (2011) Formuvannja marketynghovoji strateghiji konkurentnoji borotjby VNZ [Formation of a marketing strategy for the competitive struggle of universities].

Aktualjni problemy ekonomiky, n. 5, p. 78-82. (in Ukrainian)

KYJIVSJKYJ NACIONALJNYJ EKONOMICHNYJ UNIVERSYTET IMENI VADYMA GHETJMANA. Available: < kneu.edu.ua>. Access: 12 July 2020. 
INDEPENDENT JOURNAL OF MANAGEMENT \& PRODUCTION (IJM\&P)

http://www.ijmp.jor.br

v. 11, n. 9, Special Edition (Baltic States), November 2020

ISSN: 2236-269X

DOI: 10.14807/ijmp.v11i9.1421

LOVINSJKA, L. H.; PARASII-VERGHUNENKO, I. M.; KORYTNYK, L. P. (2018)

Osnovni metodologhichni pidkhody do orghanizaciji upravlinsjkogho obliku v zakladakh vyshhoji osvity ta metodyky vyznachennja vartosti osvitnikh poslugh [The main methodological approaches to the organization of management accounting in higher education institutions and methods for determining the cost of educational services]. In: Aktualjni problemy finansovogho upravlinnja: ghlobaljni tendenciji i nacionaljna praktyka (Jefymenko, T.I. (Ed.)]; Kyiv, DNNU «Akad. fin. upravlinnja»., pp. 437-454. (in Ukrainian).

MENDOZA, J. M.; GALLEGO-SCHMID, A.; AZAPAGIC, A. (2019) Building a business case for implementation of a circular economy in higher education institutions. Journal of Cleaner Production, v. 22020, p. 553-567. DOI: 10.1016/j.jclepro.2019.02.045.

NATROSHVILI, S. Gh. (2015) Strateghichne upravlinnja vyshhym navchaljnym zakladom: teorija, metodologhija, praktyka monoghrafija [Strategic management of a higher educational institution: theory, methodology, practice: monograph]. Kyiv: KNUTD. (in Ukrainian).

PARASII-VERGHUNENKO, I. M. (2007) Strateghichnyj analiz u bankakh:teorija, metodologhija, praktyka:monoghrafija. Kyiv: KNEU. (in Ukrainian)

POLJANSJKA, A. S.; TYMOSHENKO, D. V. (2019) Konceptualjni zasady planuvannja rozvytku zakladiv vyshhoji osvity [Conceptual framework for planning the development of higher education institutions]. Naukovyj visnyk IFNTUNGh. Serija: Ekonomika ta upravlinnja v naftovij i ghazovij promyslovosti, v. 2, n. 20, p.162-174. (in Ukrainian)

PORTER, M. (1980) Competitive Strategy: Techniques for Analyzing Industries and Competitors. N.Y.: Free Press.

RAMISIO, P. J.; PINTO, C. L.; GOUVEIA, N.; HÉLDER, N.; COSTA, H.; AREZES, D. (2019) Sustainability Strategy in Higher Education Institutions: Lessons learned from a nineyear case study. Journal of Cleaner Production, v. 222, p. 300-309. DOI:

https://doi.org/10.1016/j.jclepro.2019.02.257

RODRIGUES, P. C. C.; FERNANDES, E. M. S.; SILVEIRA, F.; SANTOS, B. M.;

MOLINAR, F. (2019) Analysis of the data on the quality expectation in school services, from the student's perception. Independent Journal of Management \& Production (Special Edition IFLOG), v. 10, n. 4, p. 1374-1388. DOI: dx.doi.org/10.14807/ijmp.v10i4.758

SALOGHUBOVA, V. (2007) Kompleksne otsiniuvannia konkurentospromozhnosti VNZ v marketynhovomu seredovyshchi rehionu [Comprehensive assessment of the competitiveness of universities in the marketing environment of the region]. Ekonomist, n. 8, p. 34-37. (in Ukrainian).

SHANK, D. Z. H.; GOVINDARADZHAN, V. (1999) Strategicheskoe upravlenie zatratami [Strategic cost management]. SPb.: ZAO «Biznes Mikro» (in Russian).

SHUHIDAN, S. M.; MASTUKI, N.; NORI, W. M. (2015) Accounting Information System and Decision Useful Information Fit Towards Cost Conscious Strategy in Malaysian Higher Education Institutions. Procedia Economics and Finance, v. 31, p. 885-895.

SYREYSHCHIKOVA, N. V.; PIMENOV, D. Y.; MIKOLAJCZYK, T.; MOLDOVAN, L. (2020) Development of a Risk Management Technique in Strategic Planning of Universities. Case study of a Polytechnical Institute. Procedia Manufacturing, v. 46, p. 256-262. DOI: https://doi.org/10.1016/j.promfg.2020.03.038. 
DOI: 10.14807/ijmp.v11i9.1421

TASKOV, N.; MITREVA, E. (2015) Total Dedication of the Top Management within the Macedonian Higher Education Institutions. Procedia - Social and Behavioral Sciences, v. 1805, p. 219-226.

THAMRINA, H.; PAMUNGKASB, E. W. (2017) A Rule Based SWOT Analysis Application: A Case Study for Indonesian Higher Education Institution. Procedia Computer Science, v. 116, p. 144-150. DOI: https://doi.org/10.1016/j.procs.2017.10.056.

URASHKO, M. I.; NAZARKO, S. O. (2010) Adaptacija matrychnykh metodiv do umov strateghichnogho rozvytku reghionaljnoji vyshhoji shkoly. Efektyvna ekonomika, n. 5. http://www.economy.nayka. com.ua/index. php?operation =1\&iid=204. (in Ukrainian).

VAJSMAN, V. A. (2004) Osnovny`e princzipy`konkurentosposobnosti sub`eta khozyajstvovaniya [Basic principles of competitiveness of a business entity]. Ekonomika i gosudarstvo, n. 7, p. 26-30. (in Russian).

YANEZ, S.; URUBURU, A.; MORENO, A.; LUMBRERAS, J. (2019) The sustainability report as an essential tool for the holistic and strategic vision of higher education institutions. Journal of Cleaner Production, v. 207. p. 57-66. DOI: https://doi.org/10.1016/j.jclepro.2018.09. 171. 